\title{
An Evaluation Study of an E-Learning Course at the Duhok Polytechnic University: A Case Study
}

\author{
Abdulraheem Jamil Ahmed, Duhok Polytechnic University, Iraq \\ (iD) https://orcid.org/0000-0003-4521-3125 \\ Falah Hasan Mohammed, Duhok Polytechnic University, Iraq \\ (iD) https://orcid.org/0000-0003-0459-2114 \\ Naji Abdullah Majedkan, Duhok Polytechnic University, Iraq
}

\begin{abstract}
In last decade, there has been a growing awareness of e-learning, which is the most recent type of distance education and has become a highly significant model of educational technology. Today e-learning studies indicate that there is an increasing use of this educational scheme for students, trainers, and instructors, which improves the learning capability of the students and trainee by depending on student-centered learning (SCL) scheme rather than using the traditional teacher or trainer-centered teaching mechanism. However, students' awareness for the advantage of using e-learning has not been significantly investigated, especially in Iraq. The aim of this article is to inspect students' awareness of the use of e-learning at the Dohuk Polytechnic University. Participants involved in this study were 100 students studying the $\mathrm{C}++$ programming language course during 2015-2016 and 2017-2018 academic years and 210 students studying a computer application course during 2018-2019.
\end{abstract}

\section{KEYWORDS}

Distance Learning, E-Learning, Learning Management System, Student-Centered Learning

\section{INTRODUCTION}

The process of distributing the electronic questionnaire form to the students participating in the course was supervised by the researchers. The results of this research showed that students have a high awareness for E-Learning system as a new approach of study and self-learning. What can be clearly seen in the research results is that students understanding for the utilization of e-Learning are significantly positive. In addition, results of this study indicated that E-Learning possibly will be as effective as traditional training and learning method, Electronic learning is a technological education that act as a substantial character in modernist education and trainee-ship. E-learning is one of the latest directions of learning that has emerged to defy the classical "bucket theory" or banking Understandable of teaching. The banking Understandable of teaching assumes that the knowledge is 
reigns by the university teacher and installment it for the students those are an ineffectual present the classrooms (A. G. Almekhlafi,2009). Its significant contribution lies in the fact that the content of the course is ready at any device and venue from a steady device to mobile device. For the time being, use of technology made the education achievable everywhere (A. G. Almekhlafi,2004). Majority of the institutes in Higher Education, utilize Learning Management Systems (LMS) to hand over their course resources to the students. E-learning is one of the latest methods of modern education in keeping with rapid development of distance learning technology. An example of how E-Learning Web Based Instruction (WBI) can influence education is the study carried out by (A. G. Almekhlafi 2005) in which they providing full online courses. Now days the online learning improve from peripheral model of education to a usually accepted and gradually more and more popular alternate to classical face to face education (A. M. Abdulazeez, S. R. Zeebaree, and M. A. Sadeeq 2018). What stands out last few years is the continual growth of utilization of E-Learning in the educational institutes. In the bright of this enlargement of research, there are yet various ongoing endeavors and highlight fields deserved for future realization (A. M. Abdulazeez and S. R. Zeebaree 2018).

Currently, the educational technologies backing robustly both teaching and learning processes (TL), which are utilized in educational medium both in classical learning and podiums across internet (i.e. E-Learning). In the recent years, the advanced technology has given aids in provided that pertinent information for everyone teaching actors (teachers, students, coordinators, and managers) expressible within various educational mediums [9], while just like that boosting he quality and inventions in the context of academic education as highlighted by (B.Alhayani,H.Ilhan 2010).

The fast development of computers and Internet technologies and its vital role in education has introduced E-Learning as substantial approach of teaching and learning. Ever the attractiveness of E-Learning to the interests and attention of learners there has been a significant an increased in requirements of multimedia educational accessories. Single of the main features of E-Learning's its ability to combine several media, like picture, text, audio, video, and animation to create an educational material for multimedia, raising the interests of readability, and readiness of the students. Even though, (WBI) is a modern field of studies on the scientific arena compared to other fields in education, it is get bigger quickly and is one of the speediest increasing corrections throughout the universe. E-Learning is the newest evolution of remoteness teaching, that became a much earnest part of teaching technology. Its spread is increasing dramatically, especially in lifelong learning and corporate training (B. Alhayani, H. Ilhan 2020). Furthermore, the researchers mentioned that social media also have a great role in learning process and contributes to the development of cooperative learning (B. H. Khan,2001). One of the latest methods of education, which is based on modern technology is e-Learning or content management system built and based on the Internet and the web (N. Gunawardena and M. S. McIsaac, 2013)]. These tools could display many interactions, for example, delivering learning content and online communication, enabling either real-time or asynchronous communication among entrants He, (K., Zhang, X., Ren, S., \& et.al. 2016). An examples of these tools or platforms are: Top-class, Moodle, WebCT, Blackboard, Google classroom, FirstClass Classrooms, CoSE and Learning Landscapes (H. Ilhan, B. ALhayani,2017).

\section{LITERATURE REVIEW}

Newly, web technology has been considered with enormous interest to overcome cost and quality issues in universities. The university students need IT in case of teaching and learning by bring into move more modernity, effectual, and efficient substitute like E-Learning. E-Learning have the role to hand over the content of the course via different types of electronic media's. For decades the notion of E-Learning has be concerning while it is the most important up-to-date expansions in the manufacture of information systems (H. M. Selim, 2007)

Since e-Learning has become one of the most powerful and prosperous tactics in learning for presenting study; by means of its abilities like increasing impulse and self-estimate at students, 
promoting educating and learning by interchanging and get access to a diversity of information resources suitability to students, trainers and institutions or universities. while the session robustly confirms online interaction, the learning will fulfil improvement, enhancing arrival to info, and Provides a flexible and effective learning environment with pace-learning management (H. M. Selim, 2007).]. Many research worker have made use of E-Learning and its possibility in the teaching system such as (Jian, C., Huibin, G., Weiguo, W., \& Xun, B. 2015). E-Learning is one of the most hopeful teaching methods. A decent sample of how E-Learning affects education is donation whole online courses or interacting multimedia CDs[19]. In different environments the researchers were study and debate the benefits of e-learning. And outcomes of their efforts have mostly been affirmed because of their many advantages (J. Wang, Z. Lu, W. Wu, and Y. Li,2005)

Jung[19] has shown that, E-Learning offer an elastic and adjustable system content using hyperlink technology. The core elements of (WBI) construction are the high flexibility in developing and updating its educational content, and graphical form. Likewise, as in[20], in an investigation to explore the impact of web- based teaching on education, declared that the outcomes showed powerful evidence in order to the usage of related the content of web on the Internet to a large extent improves learning.

The e-Learning has many aims for learning process, according to reference[4], e-Learning aims at realizing several objectives (1) recompense for any lack of teaching and training staff during the use of virtual online classrooms, (2) pervasion the utilize of technology in community, (3) Has become an opportunity to create teachers and students who are educated in technology and capable to deal with the expansion and development we are witnessing in all areas of our dialy life, (4) making a cooperative learning setting that improves learning and instruction procedures, (5) supporting the connection between educational institution and community, and (6) enhancing the contact among students, trainers and instructors over the interchange of Experiences and perspectives (e-mails, online classrooms).

\subsection{A-Learning Avails For Education System}

There are many advantages and avails can an e-Learning provides for the instructor and learner sector[21]. Following some of them: (1) It has possibility to overpowering the remoteness and time barriers, (2) through the use of different connection tools like conversation forums, talk rooms, and virtual classrooms, (3) Provides access to education for all students where it hike equality of opportunity, that is, Any learner, trainee, or student can participate in the learning process as much as he wishes without limits or obstacles from anyone, (4) reducing the managerial responsibilities for the instructor, (5) Using fairly, transparent and varied assessment methods through various electronic systems, (6) Provide self-learning chances that embrace the idea of learning from any place and anytime, (7) Education is according to the time of the student and his/her own speed, i.e. takes individual differences into account, (8) the needed costs for travel and transportation are eliminated, (9) update of materials and resources are easy and technically, and (10) finally, developing students' abilities to cooperate and exchange information and experiences among themselves through electronic educational classes (J. R. Ouyang and J. E. Yao, 2012).

Through previous studies, where some studies discussed and estimated e-Learning, furthermore investigated the perceptions of students towards e-Learning (WBI) and compared with traditional education, all these studies pointed to the optimistic possibility for implementation of e-learning for teaching and education (K. Jacksi, F. Ibrahim, and S. Ali, 2018).

Smith, \& Boone (2000) investigated the competence of online education and classical classroom. Despite the fact that, the results were similar in both categories, researchers reported that some advantages were observed in online learning platform when compared with face - to - face paradigm. As in (Khalaf, O. I., \& Abdulsahib, G. M. (2019), in an assessment of combining E-Learning into an academic course in Leadership and Administration, discover that the combination of E-Learning (WBI) to assist cooperation was efficient. So, the locations and times that were most appropriate to both students and instructors to complete their academic tasks without any restrictions. likewise, as 
in (Khalaf, O.I., Abdulsahib, G.M., Kasmaei, H.D., Ogudo, K.A. 2020), in a research of the impact of internet teaching on learning, declared that the results showed solid proof that the utilization of related web content on the Internet substantially improves learning.

In sum, from the previous literature review, it noticed that the utilize of e-learning next to traditional education hasgreat effectiveness in the teaching process, for example it can save time and effort and achieve many educational objectives.

\subsection{Problem Declaration and Significance of The Research}

Nowadays increasing student number in our universities and institutes will effect on the entire process of teaching, whether in terms of time, space, number of teachers, and etc., of other requirements. So, a functional turn into so conclusive to meet this overflowing. E-Learning can be a fine element to solve these problems related to the entire educational process. it can beat time and geographical bulkheads. Check up the interest of usage E-Learning for academic attainment is significant for the following causes: First, nowadays the Kurdistan Region is started to create e-government, including E-Learning in institutions. Therefore the Duhok Polytechnic University has strive to create and support E-Learning System during different platforms; so specific efforts have been done to combine technology into all sections around the region specially universities (M. Caris, D. Ferguson, and G. Gordon, 2002). E-Learning can help the region grow up its educational system, Second, E-Learning can spread over distant zones overcomes time and geographical barriers as it is "anytime anywhere learning system" which prove that its more powerful than the old educational scheme.

\section{RESEARCH QUESTIONS}

A survey was administered to students at the Zakho Technical Institute, Dohuk polytechnic University during 2015-2016 and 2017-2018 academic years and 210 students studying computer application course during 2018-2019.

The article attempts to discuss the following issues:

1. Do students realize interaction via e-Learning?

2. Do students realize E-Learning benefits and usefulness?

3. Do students realize E-Learning as a modern pattern of learning?

Do students realize E-Learning limitations

\section{RESEARCH METHODOLOGY}

\section{A. Participants}

The participants in this survey were students in "cpp programming language" and "computer application " courses at the Zakho Technical Institute, Dohuk polytechnic University during the 2015-2016 and 2018-2019 academic years. Around 200 students were participated in the survey.The participated involved in the course were aking the classes through face to-face traditional scheme with some supporting online curricula. Participants were male and female.

The instructor was same for all participants in E-Learning classes. For the participant who engaged in computer application course effective engagement with the content of the course via Google Classroom has been identified as part of the completion requirements for this semester. The program study of the course, syllabus, scientific materials and HomeWorks, were all available online. 


\subsection{Instruments}

A questionnaire using a 5-score scale was created during the academic years 2015-2016 and 20182019. The response scales use anchors extending from 1 represent "strongly Disagree", till 5 which represent "strongly Agree". Using Cronbach's alpha which measures the internal consistency, of a set of scale or test items, the questionnaire alpha was 0.915 which very high level of internal consistency among the questions which indicate a respectable value for the questionnaire. The purpose of the questionnaire was to find participants' realization and understanding of the use of E-Learning for learning. The study concentrated on various issues relevant to E- Learning, for example, awareness of E-Learning for participants, E-Learning benefits and usefulness, and e-Learning limitations. The questionnaire was created in Kurdish and English.

\subsection{Design}

Quantitative data collection scheme has been used in this study supported by discussion forums created in google classroom system and a complete online cpp programming language video lectures has been published on YouTube and shared on the e-learning system. Descriptive statistics method has been used for analyzing the collected data.

\subsection{Procedure}

Use of Online materials was supplemental and a supporting system for traditional face-to-face classes. The students received directions on the most effective method to utilize E-Learning at the beginning of the term. When the course was finished, students filled the demanded questionnaire. The results of this study depends on the data that has been collected from the questions included in the survey, then SPSS 15.0 and Microsoft office Excel 2016 were utilized to analyze the collected data.

\section{RESULTS AND DISCUSSION}

The aim of this research is to inspect students' student's realization and understanding of the utility of E-Learning at the Zakho Technical Institute, Dohuk Polytechnic University. Also this study aims at comparing E-Learning and traditional teaching in the classroom of academic institutions which is face-to-face learning method. and explore the possibility of implementing the full E-Learning or partially implementation and try to provide support for the traditional system.

To discuss the first issue "Do students realize interaction via E-Learning?", Research outcomes indicate that students had a good understanding for communication in an E-Learning platform. Participants' average score on E-Learning increase active interaction of among students were nearly 4.0 on a 5-score scale. Furthermore, the impact of E-Learning in increasing the percentage of communication with the teacher and trainer was 3.7 (see table 1).

To discuss the second issue by answering question number 2 "students' realization for E-Learning benefits?", results indicated that students realize E-Learning as a way of learning that has various advantages for students (see Table 2).Participants realize E-Learning as simple, uncomplicated, enjoyable, valuable, worthy, flexible, adaptable and reliable technique of learning. Moreover, they believe that E-Learning raise their capability to understand and realize the objectives of educational content. The element of time is significant for both the instructor and the student, in E-Learning learner has immediate access to the course materials at any time and any location, therefore it fit students' schedule much better than traditional classroom learning, making participants motivated to learn and improve their performance as students can learn at their own pace and speed. The average scores for all the previous benefits were nearly 4.0.

To discuss the third issue by answering question number 3 "Do students realize E-Learning as a new technique of learning?", results indicated deep understanding of E-Learning as a modern scheme of learning (see Table 3). Participants indicated that the use of this modern method of education as 


\section{students realization for interaction via e-Learning?}

\begin{tabular}{l|r|r}
\hline variable & M & SD \\
\hline $\begin{array}{l}\text { e-learning increase active interaction } \\
\text { between students and another students }\end{array}$ & 3.9 & 1.2 \\
\hline $\begin{array}{l}\text { e-learning improve my ability to } \\
\text { communicate with course instructor }\end{array}$ & 3.7 & 1.2 \\
\hline
\end{tabular}

\begin{tabular}{|l|r|r|}
\hline \multicolumn{3}{l}{ Students realization for e-Learning benefits? } \\
\hline variable & M & SD \\
\hline The course was effective and help you to & & \\
reach learning objectives. & 3.9 & 1.1 \\
\hline Was the information in the course easy to & & \\
understand? & 3.8 & 1.3 \\
\hline The course was easy to use. & 3.6 & 1.2 \\
\hline the course was enjoyable. & 3.8 & 1.2 \\
\hline e-learning increase my motivation for & 3.9 & 1.1 \\
\hline e-learning fits my Schedule better & 3.7 & 1.2 \\
\hline e-learning improved my performance. & 3.8 & 1.2 \\
\hline
\end{tabular}




\begin{tabular}{|c|c|c|}
\hline \multicolumn{3}{|c|}{$\begin{array}{l}\text { students realization for e-Learning as a method of } \\
\text { learning }\end{array}$} \\
\hline variable & M & SD \\
\hline Do you have any idea about the E-learning? & 3.6 & 1.1 \\
\hline Full online learning is better for learning. & 3.6 & 1.2 \\
\hline e-learning was helpful beside (with) & & \\
\hline traditional classroom learning? & 3.9 & 1.2 \\
\hline $\begin{array}{l}\text { e-learning is better than traditional } \\
\text { classroom learning? }\end{array}$ & 3.3 & 1.2 \\
\hline $\begin{array}{l}\text { Are you with the E-Learning to apply in } \\
\text { future? }\end{array}$ & 4 & 1.2 \\
\hline $\begin{array}{l}\text { do you recommend e-learning to other } \\
\text { students? }\end{array}$ & 3.8 & 1 \\
\hline $\begin{array}{l}\text { Would you be willing to test future e- } \\
\text { learning course. }\end{array}$ & 3.8 & 1.2 \\
\hline
\end{tabular}

\begin{tabular}{l|r|r|}
\hline \multicolumn{3}{l|}{ students realization for e-L limitations } \\
\hline variable & M & SD \\
\hline $\begin{array}{l}\text { e-learning has many problems about } \\
\text { delivering the course }\end{array}$ & 2.2 & 3.6 \\
\hline $\begin{array}{l}\text { e-learning makes it difficult to find help } \\
\text { when needed. }\end{array}$ & 1.2 & 1.3 \\
\hline
\end{tabular}


a supporting teaching system in the classroom was successful. The study also showed the desire of participants to enroll in the classrooms that use this method in education. The previous items mean score were between 3.3 to 4 as shown in the table 3. This indicates that students consider E-Learning as a modern technique of learning and delivery system useful and successful.

To discuss the fourth issue by answering question number 4 "Do students realize E-Learning limitations?", Research outcomes pointed out that participants agree that there is no substantial limits for E-Learning. average scores for both issues were nearly 2.

Research result shows that E-Learning education system might be as efficient as ordinary teaching scheme. However, this offer an advantage to E-Learning over face-to-face as it succeeded to overcome various obstacles and can solves various difficulties including economic and community concerns.

\section{CONCLUSION}

Nowadays E-Learning has been used by academical and educational institutions, but the diversity in implementation that makes the variation. It has become clear these days that the differences in the infrastructure of educational institutions as well as the culture of the environment of these institutions are one of the main factors influencing on methods of implementing E-Learning. The very positive results that implementation of $\mathrm{Cpp}$ programming language and computer application courses showed; it can be used as a reference for other subjects to implement such method. The results of this research showed that students have a good understanding of the E-Learning system as a method of study, learn and increase knowledge. In addition, this study showed that E-Learning is as effective as the traditional education system. In this case, E-Learning may solve many difficulties and problems faced by students in the system and rules of some educational institutions.

E-Learning can be utilized by educational institutions to offer learning contents that do not require practical experience under the direct supervision of the instructor or teacher. Educational institutions that offer curricula and educational courses that do not require experience and Hand skills under the supervision of a trainer or teacher they can use e-learning as a deliverance system for their educational courses. Dohuk Polytechnic University could use E-Learning as a supporting delivery system to many of its training and educational courses. The success of the E-Learning system rely on many elements, including the available physical resources such as modern technology and devices as well as human resources such as technical support provided to the system and depends on the faculty and students who wish to implement this system. 


\section{REFERENCES}

Abdulazeez, A. M., \& Zeebaree, S. R. (2018). Electronic Learning System for Duhok Polytechnic University. Acad. J. Nawroz Univ., 7(3), 249-258. doi:10.25007/ajnu.v7n3a250

Abdulazeez, A. M., Zeebaree, S. R., \& Sadeeq, M. A. (2018). Design and Implementation of Electronic Student Affairs System. Acad. J. Nawroz Univ., 7(3), 66-73. doi:10.25007/ajnu.v7n3a201

Alhayani \& Rane. (2014). Face recognition system by image processing. International Journal of Electronics and Communication Engineering \& Technology, 5(5), 80-90.

Alhayani, B., \& Ilhan, H. (2010). Efficient cooperative imge transmission in one-Way mult-hop sensor network. International Journal of Electrical Engineering Education, 6, 1-17.

Alhayani, B., \& Ilhan, H. (2017). Hyper spectral image classification using dimensionality reduction techniques. International Journal of Innovative Research in Electrical, Electronics, Instrumentation and Control Engineering, 5(4), 71-74. doi:10.17148/IJIREEICE.2017.5414

Alhayani, B., \& Ilhan, H. (2020). Image transmission over decode and forward based cooperative wireless multimedia sensor networks for Rayleigh fading channels in medical internet of things (MIoT) for remote health-care and health communication monitoring. Journal of Medical Imaging and Health Informatics, 10(1), 160-168. doi:10.1166/jmihi.2020.2691

Almekhlafi, A. G. (2004). Preservice and inservice teachers' computer use in the United Arab Emirates. J. Fac. Educ. United Arab Emir. Univ., 19(21), 1-35.

Almekhlafi, A. G. (2005). Preservice Teachers' attitudes And Perceptions of The Utility of Web-Based Instruction in The United Arab Emirates. International Journal of Instructional Media, 32(3), 269.

Almekhlafi, A. G. (2009). An evaluation study of an e-learning course at the United Arab Emirates University: A case study. Future Computer and Communication, 2009. ICFCC 2009. International Conference on, 437-442. doi:10.1109/ICFCC.2009.96

Caris, M., Ferguson, D., \& Gordon, G. (2002). Teaching over the web versus in the classroom: Differences in the instructor experience. International Journal of Instructional Media, 29(1), 61-67.

Donnelly \& O'Rourke. (2007). What now? Evaluating eLearning CPD practice in Irish third-level education. Journal of Further and Higher Education, 31(1), 31-40.

Gunawardena, C. N., \& McIsaac, M. S. Distance education, (2013). In Handbook of research on educational communications and technology (pp. 361-401). Routledge.

Hall, Watkins, \& Ercal. (2000). The Horse and the Cart in Web-Based Instruction: Prevalence and Efficacy. Academic Press.

He, K., Zhang, X., \& Ren, S. (2016). Deep Residual Learning for Image Recognition. IEEE Computer Vision and Pattern Recognition, 770-778.

Ilhan, H., \& Lhayani, B. A. (2017). Hyper spectral image classification using dimensionality reduction techniques. International Journal of Innovative Research in Electrical, Electronics, Instrumentation and Control Engineering, 5(4), 71-74. doi:10.17148/IJIREEICE.2017.5414

Jacksi, K., Ibrahim, F., \& Ali, S. (2018). Student Attendance Management System. Sch. J. Eng. Technol. SJET, $6(2), 49-53$.

Jian, C., Huibin, G., Weiguo, W., \& Xun, B. (2015). Image Super Resolution Restoration Method and Its Application. Advances in Laser and Optoelectronics, 52(02), 47-56.

Khalaf, O. I., \& Abdulsahib, G. M. (2019). Frequency estimation by the method of minimum mean squared error and P-value distributed in the wireless sensor network. Journal of Information Science and Engineering, 35(5), 1099-1112. 
Khalaf, O. I., Abdulsahib, G. M., Kasmaei, H. D., \& Ogudo, K. A. (2020). A new algorithm on application of blockchain technology in live stream video transmissions and telecommunications. International Journal of e-Collaboration, 16(1), 16-32. doi:10.4018/IJeC.2020010102

Khalaf, O. I., Abdulsahib, G. M., \& Sadik, M. (2018). A Modified Algorithm for Improving Lifetime WSN. Journal of Engineering and Applied Sciences (Asian Research Publishing Network), 13, 9277-9282.

Khan, B. H. (2001). A framework for web-based learning. Web-Based Train.

Mairal, J., Bach, F., \& Ponce, J. and et al. (2010). Non-local sparse models for image restoration. IEEE International Conference on Computer Vision, 2272 -2279.

Ouyang, J. R., \& Yao, J. E. (2012). Web-based Instruction: What should we know? Society for Information Technology \& Teacher Education International Conference, 270-27.

Qiu, R. G., \& Lee, D. (2013). Transformative education Web 2.0 systems for enriching high school STEM education. Software Engineering and Service Science (ICSESS), 2013 4th IEEE International Conference on, 352-356. doi:10.1109/ICSESS.2013.6615322

Selim, H. M. (2007). Critical success factors for e-learning acceptance: Confirmatory factor models. Computers \& Education, 49(2), 396-413. doi:10.1016/j.compedu.2005.09.004

Selim, H. M. (2007). Critical success factors for e-learning acceptance: Confirmatory factor models. Computers \& Education, 49(2), 396-413. doi:10.1016/j.compedu.2005.09.004

Sharpe, R., \& Benfield, G. (2005). The student experience of e-learning in higher education. Brookes EJournal Learn. Teach., 1(3).

Tess, P. A. (2013). The role of social media in higher education classes (real and virtual)-A literature review. Computers in Human Behavior, 29(5), A60-A68. doi:10.1016/j.chb.2012.12.032

Ventayen, R. J. M., Estira, K. L. A., De Guzman, M. J., Cabaluna, C. M., \& Espinosa, N. N. (2018). Usability Evaluation of Google Classroom: Basis for the Adaptation of GSuite E-Learning Platform. Asia Pac. J. Educ. Arts Sci., 5(1), 47-51.

Wang, J., Lu, Z., Wu, W., \& Li, Y. (2012). The application of data mining technology based on teaching information. Computer Science \& Education (ICCSE), 2012 7th International Conference on, $652-657$. doi:10.1109/ICCSE.2012.6295159

Tong, X. M., Zhang, L., Yi, Z., \& Hu, P. (2017). MBVCNN: Joint convolutional neural networks method for image recognition. AIP Conference Proceedings. doi:10.1063/1.4982456

Wang, Y.-S. (2003). Assessment of learner satisfaction with asynchronous electronic learning systems. Information \& Management, 41(1), 75-86. doi:10.1016/S0378-7206(03)00028-4

Wang, Z., Bovik, A. C., Sheikh, H. R., \& Simoncelli, E. P. (2004). Image quality assessment: From error visibility to structural similarity. IEEE Transactions on Image Processing, 13(4), 600-612. doi:10.1109/TIP.2003.819861 PMID:15376593

Wang, W., Cui, Z., Chang, H., Shan, S., \& Chen, X. (2014). Deeply coupled auto-encoder networks for crossview classification. arXiv 1402, 2031.

Wernet, S. P., Olliges, R. H., \& Delicath, T. A. (2000). Postcourse evaluations of WebCT (Web Course Tools) classes by social work students. Research on Social Work Practice, 10(4), 487-504. doi:10.1177/104973150001000408

Yu, T., \& Jo, I.-H. (2014). Educational technology approach toward learning analytics: Relationship between student online behavior and learning performance in higher education. Proceedings of the Fourth International Conference on Learning Analytics and Knowledge, 269-270. doi:10.1145/2567574.2567594 
Abdulraheem Jamil Ahmed is the Head of the Information Technology Department at Duhok Polytechnic University. He received B. Eng. In Medical Instrumentation Technology Engineering, Mosul Technical College, Northern Technical University, Iraq in 2002. He received a Higher Diploma Degree in Computer Aided Instructional Engineering, University of Technology, Baghdad, Iraq in 2003. He received a Master degree in Information Technology, M-Tech (IT) from Department of Computer Science and Engineering, JNTUH College of Engineering, Hyderabad, India in 2011. He is a member of Zakho Technical Institute Committee 2011-present. He is a director of Director of Quality Assurance Unit Zakho Technical Institute, Duhok Polytechnic University. His research interest is Wireless Networks, e-learning and neural networks.

Falah Hasan Mohammed Ibrahim received a Bachelor's degree BSc. in computer science from the University of Duhok, Kurdistan Region, Iraq in 2004, a Master's degree MSc. In computer science \& information technology from SHIATS, Allahabad, India in 2011, and present Ph.D. candidate in computer science at University Technology Malaysia, UTM, Johor Bahru, Malaysia. From 2011 to 2013 he was head of the Computer System department, from 2012 to 2017 he was head of the Information Technology department at Duhok Polytechnic University. From 2012 to present he is an Assistant Lecturer in Computer Science and IT at DPU. Mr. Ibrahim's interest in Web Technology, and Image Processing research area.

Naji Abdullah Majedkan received the B.Sc. degree in computer technical engineering from the Northern Technical University - Mosul, Iraq, 2003 - 2004, and M. Tech. degree in information technology engineering from University of JNTU, Hyderabad, India from 2009 to 2011. His general research interests are in information security, data science, operating system, and embedded system. 